\title{
Corrosion Inhibition of Aluminum in Hydrochloric Acid Solution Using Some Pyrazolocarbothioamide Derivatives
}

\author{
A. S. Fouda ${ }^{1, *}$, F.M. El-Taweel ${ }^{2}$, M. Elgamil $^{1}$ \\ ${ }^{1}$ Department of Chemistry, Faculty of Science, El-Mansoura University, El-Mansoura-35516, Egypt, \\ ${ }^{2}$ Department of Chemistry, Faculty of Science, Damietta University, Damietta, Egypt \\ *E-mail: asfouda@hotmail.com, asfouda@mans.edu.eg
}

doi: $10.20964 / 2017.12 .55$

Received: 11 September 2017 / Accepted: 19 October 2017 / Published: 12 November 2017

\begin{abstract}
The corrosion performance of $\mathrm{Al}$ in $2 \mathrm{M} \mathrm{HCl}$ in presence of pyrazolocarbothioamide derivatives have been investigated using electrochemical frequency modulation (EFM), Tafel polarization (PP), AC impedance (EIS) and mass reduction (MR) techniques. From polarization studies, the adsorption of heterocyclic compounds retard liberation of hydrogen and decrease the metal dissolution i.e. they performance as mixed kind. The protection action of the (pyrazolocarbothioamide) was examined in view of the adsorbed of its parts on $\mathrm{Al}$ surface and follows kinetic-thermodynamic model isotherm. The inhibition efficiency (IE) increment as the pyrazolocarbothioamide derivatives concentration was increasing. The IE decreases with increasing the temperature, showing that it is physically adsorbed. It was revealed that the existence of these pyrazolocarbothioamide derivatives rise the energy of activation. Pyrazolocarbothioamide derivatives run as excellent coating film to $\mathrm{Al}$ versus corrosion in chloride containing solutions. Surface analysis was examined using atomic force microscopy (AFM) analysis. The obtained data from all investigated tests are in great agreement.
\end{abstract}

Keywords: Al corrosion, HCl, PYRAZOLOCARBOTHIOAMIDE DERIVATIVES, EIS, EFM, AFM

\section{FULL TEXT}

(C) 2017 The Authors. Published by ESG (www.electrochemsci.org). This article is an open access article distributed under the terms and conditions of the Creative Commons Attribution license (http://creativecommons.org/licenses/by/4.0/). 